\title{
ONLINE TEACHING AND LEARNING - A NEW REALITY
}

\author{
Diana Marcu*, ORCID ID: 0000-0002-2696-8621 \\ University of Craiova, 13 Al Cuza St, Craiova Romania \\ *dianamolcut@yahoo.com
}

\begin{abstract}
The present paper aims at briefly summarizing the impact the 2019 - 2020 pandemic outbreak had on the educational field, when, with no prior preparation, all classes in the academic environment moved in the cyberspace, unveiling challenges for both teachers and students. The paper discusses the concepts of both online teaching and learning, their use to meet the needs of a specific category of students in different parts of the world as well as similarities and differences between the traditional and the online means of educating. The shift to mass online education has proved to be challenging, even impossible in certain areas, unveiling difficulties for all stakeholders involved. Though technology is widely used nowadays in all aspects of our lives, special focus is laid on teachers' and students' challenges, their expectations as well as their feelings regarding the new reality - that of attending all classes online in order to reach the goal: the acquisition of information and knowledge necessary in their future professional lives.
\end{abstract}

Keywords: challenges, expectations, needs, online environment, traditional education.

Rezumat. Prezenta lucrare își propune să rezume impactul focarului de pandemie 2019 2020 asupra câmpului educațional, când, fără pregătire prealabilă, toate clasele din mediul academic s-au mutat în spațiul cibernetic, dezvăluind provocări atât pentru profesori, cât și pentru studenți. Lucrarea discută atât conceptele de predare și învățare online, utilizarea lor pentru a satisface nevoile unei categorii specifice de studenți din diferite părți ale lumii, cât și asemănările și diferențele dintre mijloacele tradiționale și cele online de educare. Trecerea la educația online în masă s-a dovedit a fi provocatoare, chiar imposibilă în anumite domenii, dezvăluind dificultăți pentru toate părțile implicate. Deși tehnologia este utilizată pe scară largă în zilele noastre în toate aspectele vieții, se pune accent deosebit pe provocările profesorilor și elevilor, pe așteptările lor, precum și pe sentimentele lor cu privire la noua realitate - aceea de a participa la toate cursurile online pentru a-și atinge obiectivul: dobândirea de informații și cunoștințe necesare în viitoarea lor viață profesională.

Cuvinte cheie: provocări, așteptări, nevoi, mediu online, educație tradițională

\section{The concepts of online teaching and learning}

Nowadays, we all live in an era of constant transformations, new discoveries, unprecedented findings, a world which evolves hand in hand with the advancements in technology. Education and the instructional means are also part of this ever-changing 
process, many institutions and stakeholders taking an interest in how to better use the available technology to improve the educational process, and, thus, the ultimate goal of any instruction - the knowledge of their learners. Ever since the Internet appeared, there has been an opening of barriers in terms of space and time. The need of people to communicate, to network with their peers in other parts of the world turned the internet into a global social environment. According to [1], mass media and satellite communication, by its continuous info glut, have succeeded in bringing people and places closer than ever before, thus giving rise to the recent phenomenon of globalisation.

Education also finds its path into this virtual world, many practitioners using the Internet as an extra source of information or as a tool of turning the courses into more challenging and exciting experiences. Other institutions decide on integrating online courses into their curricula in order to meet the requests of these days. Practically, online teaching refers to the delivering of information and contents through the use of the Internet or the digital world. It is a new means of communication helped by the advances in technology.

Online learning is present under different terminologies, such as distance-learning, virtual learning, computer-assisted learning, e-learning, etc., with various definitions connected to the idea of educational materials delivered to remote audiences using computers and the Web. Ally defines it as the use of the Internet to access learning materials; to interact with the content, instructor, and other learners; and to obtain support during the learning process, in order to acquire knowledge, to construct personal meaning, and to grow from the learning experience [2]. The goals and objectives of any course or learning process remain unchanged, the difference lies in the means of obtaining or reaching them: via the traditional way or the digitalized world.

As Lehman and Conceição state in the preface of Creating a Sense of Presence in Online Teaching. How to "Be There" for Distance Learners, from an educational perspective, technology has given us the opportunity to expand our knowledge and extend our reach to people and places we never considered before. The benefits are beyond our imagination: saving us time, travel and cost; avoiding the necessity to take risks in going to other locations; allowing us to store information and knowledge and carry them with us wherever we go through mobile devices and other 'green' technologies; connecting us to diverse people all over the world and bringing us closer together; allowing us to work in virtual communities that are no longer limited to physical places; and giving us the opportunity to be present with each other without boundaries [3].

When it comes to both online teaching and learning, throughout the recent years, several studies have appeared with a focus on this new means of education. Practitioners were mostly interested in how to transfer the face-to-face courses to the virtual environment and still get the targeted results. It is known that academic institutions decided upon the integration of such courses as a result of students' needs. At the level of universities, there are students who are already employed and cannot attend all classes, yet their interest in acquiring information and knowledge in the field is at the same level with that of the students who are able to participate daily. For them, this type of distancelearning, the online courses, becomes a blessing. At the same time, we find students who are more interested in this distance-learning approach, out of different reasons: they may find the online attendance an easier approach since they are born in this era of technology, they use it frequently for other reasons and are more accustomed, not to mention feel at 
ease, to how to use technology to get better results. And for them, attending online courses represents a pleasure.

Around the world, there have been several attempts of creating exclusive online learning programs for students, but only few succeeded in the end. In the book entitled Online Learning and Teaching in Higher Education, the authors offer the successful example of the U.S.A., where, since the 1990s, the US National Centre for Educational Statistics has recorded a doubling of enrolments in the distance-learning courses as well as a significant growth in the delivery of such courses. As a result, the University of Phoenix proved a success in offering many distance-based courses via the Internet. The success of the online American universities is linked with a segmented distant learning market, strong in its vocational and professional focus. Another successful example is given by Australia (Open Learning Australia) where the geographical features have made the online distance learning extremely attractive. At the other end, the e-University project, set up in the UK for a period of three years, was closed in 2004, while the online university for Europe also failed to establish itself [4].

In Romania, there has not been any attempt of establishing an exclusive online academic provider, yet, universities around the country have invested a lot in technological facilities. Staff and students have access to e-books and e-journals, campuses and academic locations provide access to the Internet and other digitalized facilities, so that learners and teachers use them as an assistance in the process of both delivering and acquiring knowledge. Besides teaching in a traditional manner, teachers use websites to help students review material or gather additional information on the subject. At the same time, many resources such as course materials, are also available online. Therefore, we can talk about an e-learning process and not so much of an online course.

\section{The new reality - the shift to online education}

The end of 2019 and the beginning of 2020 were characterized by the emergence of a new virus which rapidly spread around the world, affecting every aspect of our lives. The pandemic changed, in a very short period, all aspects of our existence: the way we live, work, communicate, interact, alongside a totally negative impact on world's economies. Education and the learning process were also highly affected, since many countries decided to close all institutions and turn to distance education and online learning. This shift has proved to be extremely difficult, not to mention impossible in many parts of the world. According to the UNICEF report How Covid-19 is changing the world, less than half of households around the world have access to Internet. And the report continues, showing that the Internet is not the only missing technological tool learners need in order to continue their education. Of the total number of households, almost $80 \%$ possess a mobile phone, $50 \%$ a radio, and almost $50 \%$ television. Of course, rural areas are mostly affected, but the situation is not great in some urban areas as well [5]. In Romania, according to the National Institute of Statistics, in $2020,78.2 \%$ of the total number of households have home internet access, with differences between the urban $(84.8 \%)$ and rural $(69.7 \%)$ areas [6].

Besides the access to technology, which is vital in an exclusive online learning environment, all stakeholders in the educational field were faced with the challenge of adapting their courses fast to a new means of educating. And this is a very difficult task to achieve, especially when one deals with lack of time for preparation. The European 
Commission helped, by offering several online learning platforms for teachers and educators which could be accessed in order to ease their tasks and even exchange ideas and resources depending on their needs. Several examples of platforms are: School Education Gateway, e-Twinning, Learning Corner, EIT - European Institute of Innovation and Technology, etc. [7]. At the academic level, universities in Romania have been closed for face-to-face courses since March 2020, so all courses were moved to the online environment, with access to different e-learning platforms: Moodle, Zoom, Google Classroom, WebEx, etc.

These rapid changes have taken aback most teachers and students since they were, all of a sudden, placed in a situation they hadn't encountered before. Especially at the beginning, feelings of anxiety, fear of unknown, uncertainty arose among them. Teachers were preoccupied with the urgent need of designing their courses for the online format so that they still deliver a high-level of academic knowledge which suits the demands of the learners. Students were faced with the unknown, being somehow reserved towards what it is expected from them in this new educational environment.

\section{Teachers' challenges and expectations}

Once the decision of moving all academic courses online, a series of challenges unveiled in front of educators. Though many researchers have given attention to online teaching and published studies related to it, again, the short time for preparation represented the greatest challenge. In traditional classes, technology is generally used as a helping tool in providing information and experience.

When teaching online, technology not only serves as background, but also as a context for instruction, since it functions as the place where teaching and learning happen. That is, the place of the course is cyberspace, as that is where instructors and students interact, exchange information and ideas, make course products, and otherwise carry out the work of the course [8]. Planning a course online is not totally different from the traditional way of assembling it. The goals of the course remain unchanged, the objectives as well, while the requirements and tasks are not to be drastically changed, but rather adapted. Both in traditional and online education, according to Boncea, teachers and trainers alike should prepare future graduates for the realities that the employment market relies on [9].

When an academic institution decides upon the integration of a certain online course, teachers have the possibility of designing it thoroughly, while, in the case of the pandemic outbreak, teachers were faced with the decision to continue their teaching online, without any prior preparation. So, most of them, had to 'learn by doing', experiencing and changing aspects when needed. The courses couldn't be designed for the online activity from the beginning, they were adapted 'on the way', mostly in a fast-pace, so that they met the outcomes. Nilson and Goodson talk about specific phases of an online course design: analysis; design; development; teaching and learning; evaluation; revisions [10]. Well, at the beginning of 2020, teachers did not have sufficient time to prepare such a course, all they could do was to adapt the course to the requirements of the online system. While teaching and learning, they had to adapt assignments and evaluation methods to the characteristics of the virtual world. And not only: new activities and tasks had to be designed so that students could better understand the content of the subject and get engaged in the entire process of knowledge acquisition. The designed activities should provide opportunities for 
students to find a bridge between what they already know, and that which they have read, heard or seen in the e-lecture. Students need opportunities to reflect on the ways in which their individual understanding aligns with that of the lecturers, and the ways in which it is different [11].

In order to get the most out of the teaching process, teachers constantly need to change roles, depending on situations and, this is valid both for physical presence courses and online ones. Teachers' behavior during a class leaves an impact on both the general opinion of students on the subject taught as well as on the enthusiasm learners show when attending the classes. It's not sufficient to offer the necessary information, nor to communicate the latest, updated data if the teacher does not empathize with the students and is unable to connect with them closely. Bender discusses the six teaching roles that McKeachie (1978) identified in traditional classes and believes all of them can also be applied to the online environment. The teacher can be a facilitator who enhances student learning by encouraging active participation in discussion and by helping the students to see education as meaningful and relevant [...]; an expert who communicates expertise through lectures and discussions, and is able to stimulate students without overwhelming them; a formal authority who helps students by establishing boundaries such as acceptable conduct and dates of submission of material; a socializing agent who has contacts within the larger academic community, and as such can be helpful to students providing such things as letters of recommendation and links to research and publication sources; an ego ideal who is charismatic and shows commitment and enthusiasm not only to the subject matter but also to the students themselves; a person who demonstrates compassion and understanding of student needs [12]. Indeed, I believe all these roles are vital in establishing long-term relationships between teachers and students, relationships based on mutual respect, empathy and understanding, yet, the degree in which such reports are settled are somehow different in the online versus face-to-face meetings. We connect better with one another when we meet in person since, from the beginning, we form certain opinions easier based not only on what we say and how we react but also on the body language which cannot be always perceived online.

In the traditional way of teaching, you, together with the group, create a specific atmosphere of the class, a certain dynamic which cannot be transferred online. If voice and intonation are still kept in the live sessions of online courses, reactions, gestures, expressions, the entire body language cannot be fully transposed on a screen and this changes the entire process of communication. Online, students cannot interact with one another with the same naturalness found in a face-to-face meeting. Teachers are there for them, yet, they cannot observe them as they would in a traditional class.

Then, there is the matter of the type of subject taught. If many courses can be delivered online, without having to change content, tasks, activities, there are some which make this mission almost impossible. When we deal with subject matters which include practical activities in laboratories, the online environment cannot be of help. Students cannot experiment at home, they lack the resources and the necessary guidance. In my opinion, these were the specializations mostly affected in the learning process, since they couldn't have access to labs and experiments, only to the theoretical approach of the subject. If one can easily move a course on the cyberspace, such as philosophy, foreign languages, literature, business studies, or any other subjects which are mostly based on the theoretical approach, followed by discussions and debates, other, such as chemistry, areas 
of medicine, design, and so on, require the physical presence of both educators and learners in a lab. No matter the degree of teacher's involvement as a moderator in the class, offering the students the freedom to participate in debates, expressing opinions to make the course challenging and attractive, there are specializations where students need to test, experiment, 'touch', discover, to adapt knowledge to practical experience.

\section{Students' challenges and expectations}

When deciding upon enrolling in a distance-learning course, learners have specific expectations right from the beginning. These courses meet their expectations and needs. First, there are employees interested in continuing their studies while working, or taking up a different specialization they need at the present workplace, then, there are students who live remotely from the academic location who need to save money on travel and accommodation, or others who are interested in enrolling at a certain, prestigious university and these online courses suit their needs best.

Students enter an online course with the expectation that the course will be more attuned to their needs as learners. This may mean that the course is more convenient for them because of distance or because of work and family demands [13].

Distance-learning students differ from those who take up traditional, face-to-face courses in many ways, therefore their expectations are also different. Based on their higher age, there are certain features that relate to their expectations:

* Students will usually have a much greater experience of life. This means that they approach their studies quite differently, have a different attitude and assess it differently.

- Most of them bring considerable experience of working life to academic courses, and this also has an effect on the ways in which they study, in particular when the studies and the professional experience cover the same field [...].

- Many of them come from backgrounds in which academic studies were not offered when they were younger, and they use distance education as a second chance [...].

- There are distance students who want to reach a higher socio-economic status as a result of their experiences at work. Those are the upwardly mobile students.

- Distance-learning students have more qualifications than students in traditional universities. Many achieved considerable success at school (even where they finished their education in evening classes, for example), and at university, and above all in their professions. This naturally has an effect on their motivation and their attitude to their studies.

- Studying at a relatively late age has in general a completely different function than with 19 - 25 year-old students because it fits into plans for life and lifecycles in a different way [14].

To all these students, the online education is the approach which best suits their needs as well as their expectations. But, what happens to those students who enrolled in physical-presence studies and were faced with the unpredicted situation of attending all classes online? This is a question which doesn't have a full-size answer at the moment, it needs further analyses when this period ends, so that to get a clearer view of how the students perceived the online learning experience, how the process met or not their expectations and the general impact it had on their student lives.

When discussing with my students at the Faculty of Electrical Engineering about their feelings of meeting and learning online, at the beginning, students were somehow 
reserved about moving the process into the cyberspace, since they were more preoccupied with what it would be expected from them in the online environment rather than how to use technology in their learning process. With proper guidance from the teachers, their fears of unknown were rapidly forgotten and they could focus on the purpose of the learning process. At the same time, the digitalized world did not represent an issue for most of them since they considered it a user-friendly environment. They were able to understand the content of the subject matters, they easily dealt with the online tasks and requirements, so, the online environment did not pose any special issues for them. This latter aspect is easily understood if we take into consideration the fact that most of these students were born and raised in the technological world, they've been accustomed to computers, programs and the virtual world in general ever since they were very young.

Yet, by the end of the semester, most of them said they started missing the physical interaction, the face-to-face meetings both with their peers and teachers and hoped for a rapid return to the traditional way of learning. In their opinion, the online environment, though proficient in content, couldn't supplement the need to interact, to bond relationships with one another, to get to know their teachers and colleagues better as it usually happens when they meet at college daily. In their case, they also lacked the applicative activities since, the engineering field implies working in labs, conducting experiments, placing theory into practice. So, no matter how well an online course develops, independently of its outcomes, in the case of students primarily interested in the physical-attendance courses, the online environment did not meet their demands.

\section{Conclusions}

Online teaching and learning represents a great means of educating when it meets the needs and expectations of all stakeholders involved in the process. Out of diverse reasons, many learners choose this approach since it best suits their needs and motivates them in their quest of acquiring the necessary knowledge. This applies to those programs specifically intended to take place in the cyberspace, for a particular category of students, yet, it cannot be transformed into a mass educational technique, at least not for the moment, since many students are still eager to learn in the traditional way.

The pandemic which started in 2019 - 2020 and which conducted to a shift of all courses to the online environment, no matter their specificity, unveiled challenges for both teachers and learners. Though many of the courses proved to be a success from the point of view of their content, teachers and students being highly involved in the process of delivering and acquiring necessary knowledge, the need to physically interact, to create links with one another represented the greatest wish of learners during this period.

Even for the advocates of face-to-face teaching and learning, technology still remains a great tool to be used in classes for additional information, for the creation of exciting tasks and activities, a great complement to the subjects discussed in class. The full impact of the mass online studies during the pandemic is to be further surveyed and analyzed when the period ends and both students and teachers return to a certain approach of instruction - traditional or virtual, depending on their needs and preferences.

Therefore, a conclusion may be drawn: the success of the educational process is related to what learners expect from the beginning, when they enroll to a specific program: if they are interested in the traditional way of education or the virtual environment. 


\section{References}

1. Bălănescu O. The Fall of Communism and Its Impact on English Teaching and Learning, in Revista de Științe Politice. Revue des Sciences Politique, 61/2019, Craiova: Universitaria, pp. 57-67.

2. Ally M. Foundations of Educational Theory for Online Learning in The Theory and Practice of Online Learning, edited by Terry Anderson, AU Press, 2008, p. 17.

3. Lehman R.M., Conceição, S.C.O. Creating a Sense of Presence in Online Teaching. How to "Be There" for Distance Learners, Jossey-Bass Guides to Online Teaching and Learning, Wiley \& Sons, 2010, Introduction, p. vii.

4. Bach S., Haynes Ph., Smith J.L. (2007) Online Learning and Teaching in Higher Education, Open University Press, 2007.

5. UNICEF report How Covid-19 is changing the world, A statistical Perspective [online]. Volume I, May 2020. [accessed on 19.02.2021].

Available: ttps://data.unicef.org/resources/how-covid-19-is-changing-the-world-a-statistical-perspective/

6. INS Press Release, January, 2021. [online]. [accessed on 19.02.2021] Available: https://insse.ro/cms/sites/default/files/com_presa/com_pdf/tic_r2020.pdf

7. official website of the European Union, Education and training. [online]. [accessed on 18.02.2021] Available: $\quad$ https://ec.europa.eu/education/resources-and-tools/coronavirus-online-learningresources/online-platforms_en

8. Howell Major C. Teaching Online. A Guide to Theory, Research, and Practice. Johns Hopkins University Press, 2015, p. 10.

9. Boncea I.J. Teaching and Training Approaches during Technical English Classes in Annals of the University of Craiova, Year XIV, no.1/2018, p. 37.

10. Nilson L. B., Goodson, L.A. Online Teaching at its Best. Merging Instructional Design with Teaching and Learning Research. Wiley \& Sons, 2018, pp. 39-40.

11. Alexander Sh., Boud, D. Learners still learn from experience when online, in Teaching and Learning Online. Pedagogies for New Technologies, Routledge, 2001, p. 8.

12. Bender T. Discussion-based Online Teaching to Enhance Student Learning. Theory, Practice, and Assessment. Stylus Publishing LLC, 2003, p. 12

13. Palloff R.M., Pratt, K. Lessons from the Cyberspace Classroom: The Realities of Online Teaching. Wiley, 2001, p. 123.

14. Peters O. Learning and Teaching in Distance Education. Pedagogical Analysis and Interpretations in an International Perspective. RoutledgeFalmer, 2004, p. 13. 